\title{
Linking Theory to Practice: Science for Students with Visual Impairment
}

\author{
Aydın Kızılaslan* \\ Department of Special Education, Agri Ibrahim Cecen University, Agri, Turkey \\ *Corresponding Author: ydnkizilaslan@gmail.com
}

\section{ABSTRACT}

This study examined the effectiveness of instructional design to teach science concepts to visually impaired students. The study was conducted through case study. The study consisted of three stages. The first stage identified the visually impaired students' learning needs related to the concepts of the structure of matter. The second stage designed and developed the instructional materials, activities, and instruction. The third stage analyzed the effectiveness of the instructional design. The study's sample consisted of seven students. Data were collected through multiple choice tests and interviews. Significant differences in the academic performances indicated that instructional design had positive effects in teaching and learning science concepts for visually impaired students. As a result, students with visual impairment need appropriate adaptations and individual instructional design to compete and advance in learning the science concepts.

KEY WORDS: academic achievement; science activity; teaching science; visually impaired students

\section{INTRODUCTION}

S cientific literacy, the knowledge and understanding of scientific concepts and processes, enables people to use scientific principles and processes to make personal decisions and debate important issues involving science and technology (Bybee et al., 2009). Therefore, science literacy is more about being able to apply science concepts to explain what you observe and less about knowing facts off the top of your head (Dani, 2009). Scientific literacy requires many of the skills that people use every day such as solving problems creatively, thinking critically, working cooperatively in teams, using technology effectively, and valuing life-long learning (Millar, 2006). In other words, scientific literacy means that an individual will be able to identify questions, engage with scientific ideas to determine answers of questions derived from curiosity about everyday experiences. It means that individuals are able to use scientific evidence to explain scientific phenomena to describe, explain, and predict natural phenomena. When engaging in scientific inquiry process, students can identify questions that can be answered through scientific investigations, use appropriate tools and techniques to gather, analyze, and interpret data, develop descriptions, explanations, predictions, and models using evidence, test those explanations against current scientific knowledge, and communicate on their ideas to others (Fradd and Lee, 1995).

Science education has been identified by some special educators as one of the most useful and valuable content areas for students with disabilities (Hadary and Cohen, 1978; Patton and Andre, 1989). It was emphasized by the
National Committee on Science Education Standards and Assessment (NSES) that, "the commitment to science for all implies inclusion not only of those who traditionally have received encouragement and opportunity to pursue science but also of women and girls, all racial and ethnic groups, the physically and educationally challenged, and those with limited English proficiency" (NSES, 1993. p. 5). Due to the fact that science is accepted as one of the core subjects relating to the life of all students, it is seen as necessary for the full realization of a human being and essential to prepare students for the transition to the increasingly technological workforce (Gurganus et al., 1995).

Science is concerned with the development of cognitive skills through the first-hand experience concerning scientific activity. Acquiring scientific language, making observations, taking measurements, gathering, analyzing and interpreting data, making generalizations, creating models, communicating and carrying out investigations are some essential skills of science that can be fostered through scientific activities (Wild et al. 2013). The development of many concepts, skills, and attitudes in science is associated with hands-on science activities. By means of science activities, students are actively participating in the science process by combining "hands on" with "minds on" activities. In other words, students develop their understanding of science concepts by linking scientific knowledge with reasoning and thinking skills (Breslyn and McGinnis, 2011).

Students with disabilities need to have access to an expanded core curriculum that enables them to participate in hands-on 
science activities with their peers. The teaching of science has been recommended to be learner-centered, proceeding from the known to the unknown, involving realistic manipulatives, and interactives using materials from their environment (Wild and Trundle, 2010). It has been argued that this approach will increase students' awareness and appreciation of science (Andrews, 1998; Byrne, 2014; Browder et al., 2010; McGrail and Rieger, 2013; Thomas and Imrie, 2008).

Science education is less accessible to students with visual impairments due to the fact that it includes many abstract concepts. These students typically need a variety of opportunities to explore and examine real materials or models by touch or putting across through residual visual observation (Gast et al., 1992; Wright and Wright, 1998). As they are visually impaired, some accommodations should be done for safe and full access to the science curriculum through collaboration and specific adaptations both in the science classroom and in the laboratory (Mastropieri and Scruggs, 1992; Maguvhe, 2003). We note that there are many manuals existing, which explain how to teach science to students with visual impairments and to produce evidence-based practices. Recent research on these manuals, however, indicates that the majority of the studies focus on different topics in science such as conceptual understanding, development of scientific process skills, teaching science concepts, the effectiveness of these curriculum materials, and inclusion (Erwin et al., 2001; Fraser and Maguvhe, 2008; Hadary and Cohen, 1978; Kizılaslan and Kizılaslan, 2018; Kumar et al., 2001; Rule, 2011; Wild and Trundle, 2010).

Therefore, carefully revising and rearranging the science education curricula, and considering how to make it accessible with characteristics of students with disabilities is the crucial point that special educators should keep in mind (Scruggs and Mastropieri, 1993; Tindal and Nolet, 1994). This requirement is also highlighted by the Individuals with Disabilities Education Improvement Act (IDEA) as science teachers should provide all students with access to the general curriculum to the maximum extent possible (IDEA, 2004).

However, there are various issues related to the science education of visually impaired students. These issues relate to accommodating these students in science instruction and education inadequately (Kumar et al., 2001). Students with visual impairments have the same range of cognitive abilities as other students, they obtain information through other sensory modalities (auditory, tactile and olfactory) and the information obtained may be limited and confusing (Calderon and Naidu, 1999; Hartmann, 2013). Therefore, these students' unique needs are often ignored when determining how to make materials accessible. To exemplify, instructional materials developed for visually impaired students may cause the necessity of use of measuring devices, reading charts and written materials, and laboratory equipment to be ignored. Distinction must be made between compensatory skills and functional skills so that students with visual impairments can access the curriculum. In addition to students' accessibility of the curriculum and materials, science teachers' lacking professional awareness about science teaching is another challenge in science teaching. As highlighted by Cawley (1994), science teachers generally have little training or experience with teaching science to the visually impaired students. The great majority of the instruction in special education is explicit, in which the teacher is in full control of the various steps of the whole process of teaching. Hence, curriculum reorganization, materials, the instructional procedures, and the awareness of science educators should be taken into consideration to meet the needs of students with impairments in science teaching.

In this study, we developed an instructional design to teach the concepts of "structure of matter." This study sought to address the following questions:

1. What are students' learning difficulties related to the concepts of "structure of matter"?

2. What is the effectiveness of the activities to teach "structure of matter?"

\section{METHODOLOGY}

The study was conducted through design-based research. It is a methodological strategy for studying a wide range of designs to create and extend knowledge about developing, enacting, and sustaining innovative learning environments (Collins et al., 2004). Design based research is an important methodology for improving educational practices through iterative analysis, designing, development, and implementation of educational innovations work in practice, to narrow the gap between theories (Anderson and Shattuck, 2012).

The ADDIE model was used to develop this study's "structure of matter" instructional design as it includes analysis of students' needs, designing, development, and implementation of the instructional model, and evaluation of the learning environment, teaching, assessment-evaluation, and even external factors (Branch, 2009). Evaluation is made throughout the design process. The main purpose of the evaluation is to get feedback about all stated goals of the learning process or instruction model to fulfill the specified needs defined at the analysis phase.

As seen in Figure 1, the embedded single-case study was used to get enrichment data about students' needs. Embedded case studies involve more than one unit of analysis and usually are not limited to qualitative analysis alone (Yin, 2014). The subunits, sorted as students' needs related scientific process skills, conceptual understanding, physical environment, teaching, learning, and assessment-evaluation process were used to determine the significant contribution of subunits to the single case.

As seen in Figure 2, the study was carried out in three steps. The case study was used in the first and third steps of the study. The first step was the analysis phase, visually impaired students' essential needs related to the conceptual understanding of the "structure of matter" were defined. In addition, the data of the 
needs analysis sample group were used to identify students' essential needs related to the physical environment, teaching, learning, and assessment-evaluation process.

In the design phase of the second step, instructional materials (instructor's guide and student handouts) and activities and activity materials were designed for concepts related to "structure of matter" in terms of the needs determined at analysis phase. In accordance with this purpose, all learning outcomes related to this unit analyzed and classified according to Bloom's Revised Taxonomy. As a result of this analysis, 9 activities were designed. An activity is able to cover more than one learning outcomes. For example, the motion energies of each molecule may be different and will change with collisions and interpret the temperature as a sign of the average kinetic energy of the molecule, are two learning outcomes for teaching the concept of temperature.

After designing the activities and materials, the teaching methods and techniques were determined. In addition, assessment tools were prepared to evaluate the effectiveness of the instructional design. Then, the instructor guide was prepared. The instructor guide was designed to be a comprehensive tool for facilitating the course.

This instructor guide is the foundation for an organized approach to learning and contains information: About the subject; about the stage, class or level; about the topic; and lesson unit; about the common misconceptions of students about these concepts; about further materials such as the textbook, and possibly any source references. This makes it easier for teacher to review specific topics, to keep their worksheets well-organized, and to repeat exercises when necessary, to determine aspects of teaching and assessment where students can be given choice or flexibility, and to plan ways of providing regular, meaningful feedback to students. The student activity guide was prepared as a primary tool to help the students learn and understand each activity's content. Activity materials were developed in accordance with material development principles. These principles were designated by special education and science education scholars. To establish conceptual familiarity between activities and real life, simple materials from everyday life were used. For the students with low vision Century Gothic font and font size 18 and the blind students Braille documents were designed and used (Appendix 1 and 2). Century Gothic and font size 18 have been identified as the best readable font by visually impaired students (Çakmak et al., 2014).

The interview form to assess students' conceptual learning and achievement tests were developed to analyze the effectiveness of the design. Two different tests (pre-test and post-test) were prepared to determine the students' academic achievement. Before the implementation of instructional design, the pretest measured the students' preliminary knowledge level. After the implementation of instructional design, the post-test determined what, if any, meaningful changes occurred in the students' academic success.

The achievement tests consisted of 10 questions. Questions were revised according to the experts' feedback. In the needs analysis phase, the students complained about too many questions in the multiple-choice tests during exams. For

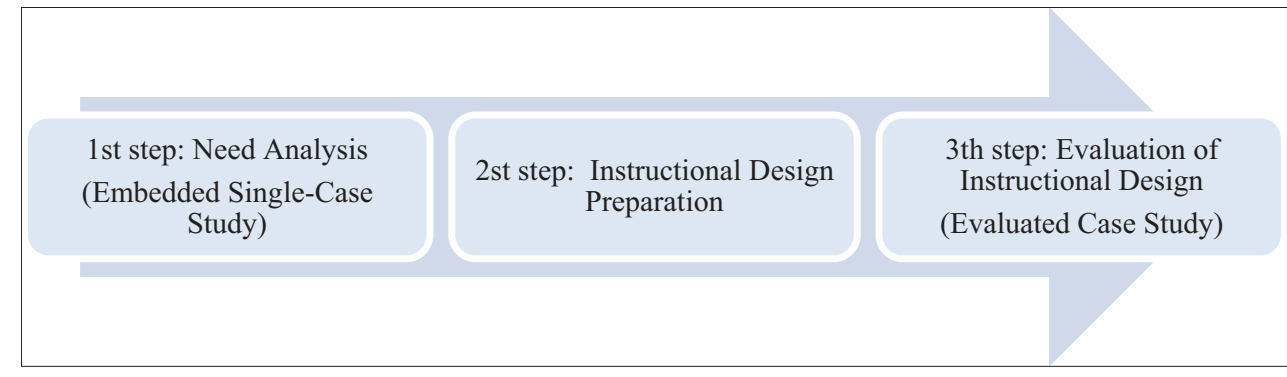

Figure 1: Method of the study

$\begin{aligned} & \text { Analysis: Students' essential need analysis related environments that maximize } \\ & \text { academic and skill development were analyzed }\end{aligned}$
$\begin{aligned} & \text { Design: Learning outcome and the skills that enable to gain were classified) } \\ & \text { Development: Essential material development principles were defined and } \\ & \text { instructional material and activity were developed } \\ & \text { Implementation: Implementation of instructional design model was applied to the } \\ & \text { students with visual impairment }\end{aligned}$
$\begin{aligned} & \text { Evaluation: Evaluation of instructional design was done by interview and achievement } \\ & \text { test }\end{aligned}$

Figure 2: Steps of the study 
this reason, the achievement tests were prepared with only 10 questions. In addition to the achievement tests, a semistructured interview form was used for assessing the students' conceptual understanding levels. Learning outcomes were taken into consideration while interview questions were being prepared. Interview questions were prepared and revised according to the science and special educators' opinions.

In the implementation phase, the instructional design was applied to six $8^{\text {th }}$ grade visually impaired students. The implementation of the study lasted nearly 3 weeks. Activityoriented instruction (AOI) was used as the teaching method of the instructional design. AOI enables students to make judgments on subject-based activities and observations and emphasizes the interaction of the teacher and students. AOI enables students to improve their reasoning and problemsolving skills, provide an opportunity for students to make the connection between the activities and concepts (Batd1, 2014).

In the final step, the appropriateness and effectiveness of the instructional design were analyzed through the data collection tools. Academic achievement tests and semi-structured interviews were subjected to descriptive analysis. As seen in Figure 3, evaluated single-case design was used at this step. Evaluative case studies involve in-depth description, explanation, judgment, and analysis of causal links of a program, project, or other development activity (Merriam, 1988).

\section{Sample of the Study}

The study included purposive sampling. Purposive sampling enables researchers to examine a specific characteristic and feature or function about sampling (Allen, 1971). Semistructured interviews were used for the students' unique needs analysis for the in-class observations and after the end of the unit. Because it is impossible to implement the instructional design to needs analysis group in the same semester, the instructional design was implemented one semester later. Both sample groups included $6^{\text {th }}$ grade students. As seen in Table 1, the sample consisted of seven students; all male except one, and one of the male students was totally blind.

\section{FINDINGS}

The results of the analysis of interviews, observation, and achievement tests are presented as: A needs analysis stage results and implementation stage results.

\section{The Result of the Needs Analysis Stage}

This section does not attempt to present all the data. A representative sample is included. For example, a student with a low vision could not tolerate direct light from the windows. As a result, he tied to protect his eyes from this direct light. The student protects his eyes from the extreme light from the window. This is just one of the situations where light intensity should be changed for the setting environment. This problem could be solved by using a curtain.

It was observed that no activities, instructional materials, or enlarged texts were used during the lessons. Furthermore, the lecture information was not presented in a visual format on the board, and the teacher did not repeat aloud what was written on the board.

\begin{tabular}{llll}
\hline \multicolumn{3}{l}{ Table 1: Analysis of sample groups } \\
\hline Student code & Visual acuity & Gender & Level of inadequacy \\
\hline $\mathrm{S}_{1}$ & Blind & Male & Totally \\
$\mathrm{S}_{2}$ & Blind & Male & Both eyes \\
$\mathrm{S}_{3}$ & Low vision & Male & Both eyes \\
$\mathrm{S}_{4}$ & Blind & Male & Both eyes \\
$\mathrm{S}_{5}$ & Low vision & Male & Only right eye \\
$\mathrm{S}_{6}$ & Low vision & Female & Both eyes \\
$\mathrm{S}_{7}$ & Blind & Male & Both eyes \\
\hline
\end{tabular}

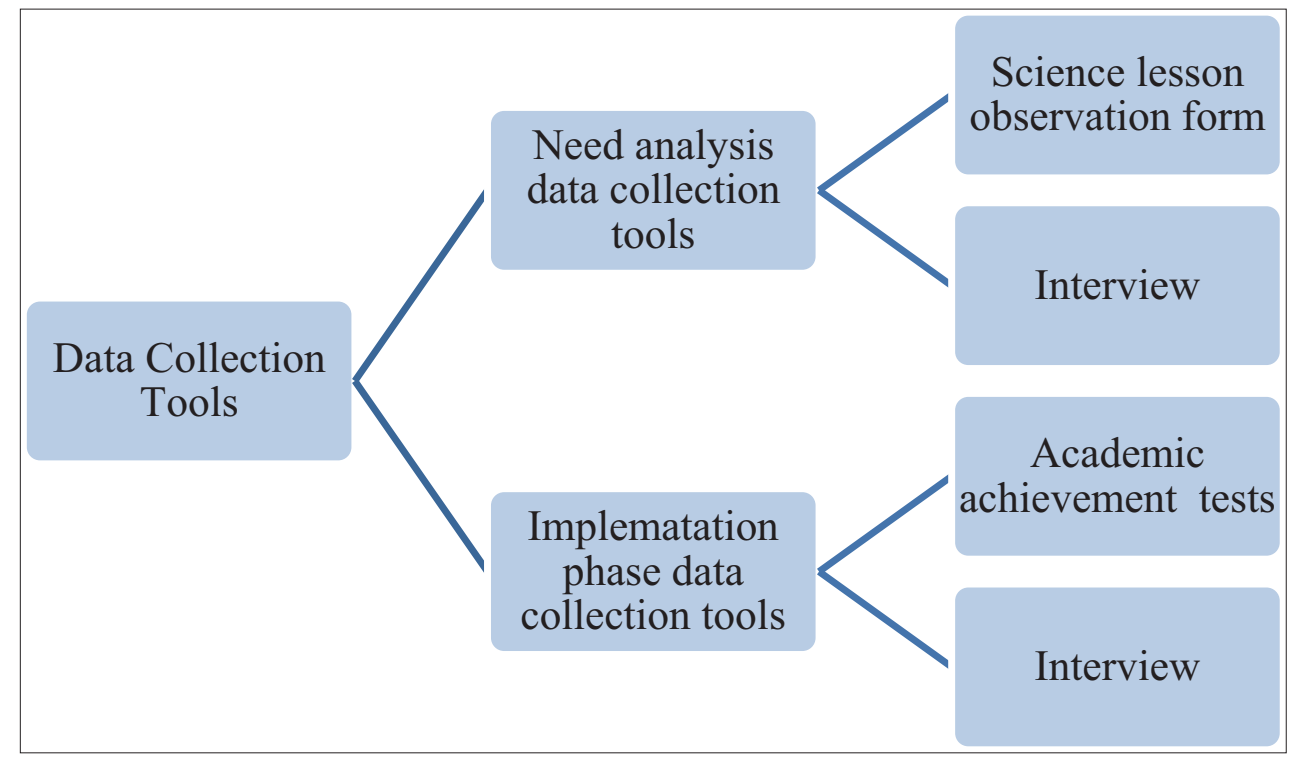

Figure 3: Data collection tools 
The instructional design to teach science concepts to visually impaired students was prepared in line with the needs mentioned above. The teacher was a novice science teacher just starting a career in teaching. The fundamental training about design activities, activity materials, and teaching methods and

\begin{tabular}{|c|c|c|c|c|c|c|}
\hline \multirow[t]{3}{*}{ Concepts } & \multicolumn{6}{|c|}{ Concept learning levels of students } \\
\hline & \multicolumn{5}{|c|}{ Students } & \multirow[t]{2}{*}{$\%$ Achievemen } \\
\hline & $S_{1}$ & $\mathrm{~S}_{2}$ & $\mathrm{~S}_{3}$ & $\mathrm{~S}_{4}$ & $\mathrm{~S}_{5}$ & \\
\hline Atom & - & + & + & - & - & 40 \\
\hline Elements & - & + & - & + & + & 60 \\
\hline Matter & - & - & - & - & - & 0 \\
\hline Solid & - & - & - & - & - & 0 \\
\hline Liquid & + & - & - & + & + & 60 \\
\hline Gas & + & + & - & - & - & 40 \\
\hline Compound & - & - & - & - & - & 0 \\
\hline Pure Substance & + & + & + & + & + & 100 \\
\hline Heterogeneous Mixture & + & - & + & - & + & 60 \\
\hline Homogeneous Mixture & + & - & + & - & - & 40 \\
\hline$\%$ Achievement & 50 & 40 & 40 & 30 & 40 & \\
\hline
\end{tabular}

Table 3: Analysis of concept of pre-test and post-test question

\begin{tabular}{ll}
\hline Questions & The questions related to concept \\
\hline $\mathrm{Q}_{1}$ & Atom \\
$\mathrm{Q}_{2}$ & Elements \\
$\mathrm{Q}_{3}$ & Matter \\
$\mathrm{Q}_{4}$ & Solid \\
$\mathrm{Q}_{5}$ & Liquid \\
$\mathrm{Q}_{6}$ & Gas \\
$\mathrm{Q}_{7}$ & Compound \\
$\mathrm{Q}_{8}$ & Pure substance \\
$\mathrm{Q}_{9}$ & Heterogeneous mixture \\
$\mathrm{Q}_{10}$ & Homogeneous mixture \\
\hline
\end{tabular}

techniques was given to the teacher before the instructional design was applied.

The analysis of interviews about students' learning level of the concepts related to the "structure of matter" is given in Table 2. As seen in Table 2, the students' correct answers are shown as plus whereas the wrong answers are shown as minus. According to this result, the concepts of matter, solid and compound were not learned. While $40 \%$ of students did learn about atom, gas and homogenous mixture concepts, $60 \%$ of them were successful in element, liquid, and heterogeneous mixture. Notably, all students were able to learn about pure substance concepts.

\section{The Result of the Implementation Stage}

In this section, the data of the descriptive analysis collected from achievement test and interviews were used to analyze students' conceptual understanding of concepts related to the "structure of matter." These academic achievement tests were conducted to measure the difference between the academic achievement levels of the students before and after the implementation of the instructional design. The academic achievement levels analysis of the students was used to determine the contribution of the instructional design on the science concepts learning. The concepts and topics included in the tests are given in Table 3. For example, the first question $\left(Q_{1}\right)$ measured the knowledge of students about the concept of heat in both pre- and post-test.

As shown in Table 4, the correct answer given by the students to each question is shown as plus and the wrong answer as minus. There are two categories in the table where the correct answer percentage is located. The first one at the bottom of the table shows the percentage of the correct answers that a student gave to all questions while the second one placed vertically shows the percentage of the correct answers that students gave to each question.

\section{Analysis of Pre-Test and Post-Tests}

According to Table 4, while the percentages of the students answer to the first and sixth questions related to the concepts

Table 4: Analysis of pre-test and post-test results

\begin{tabular}{|c|c|c|c|c|c|c|c|c|c|c|c|c|c|c|c|c|}
\hline \multirow[t]{3}{*}{ Questions } & \multicolumn{7}{|c|}{ Pre-test } & \multirow{3}{*}{$\begin{array}{c}\text { Correct } \\
\text { answer (\%) }\end{array}$} & \multicolumn{7}{|c|}{ Post-test } & \multirow{3}{*}{$\begin{array}{c}\text { Correct } \\
\text { answer (\%) }\end{array}$} \\
\hline & \multicolumn{7}{|c|}{ Students answer } & & \multicolumn{7}{|c|}{ Students answer } & \\
\hline & $\mathrm{S}_{1}$ & $\mathrm{~S}_{2}$ & $\mathrm{~S}_{3}$ & $\mathrm{~S}_{4}$ & $S_{5}$ & $\mathrm{~S}_{6}$ & $\mathrm{~S}_{7}$ & & $\mathrm{~S}_{1}$ & $\mathrm{~S}_{2}$ & $\mathrm{~S}_{3}$ & $\mathrm{~S}_{4}$ & $\mathrm{~S}_{5}$ & $S_{6}$ & $\mathrm{~S}_{7}$ & \\
\hline $\mathrm{Q}_{1}$ & - & + & - & - & + & - & + & 42 & + & + & + & + & + & + & + & 100 \\
\hline Q2 & - & - & - & - & + & + & - & 28 & + & + & + & - & + & + & - & 71 \\
\hline $\mathrm{Q}_{3}$ & + & - & - & - & - & - & - & 14 & + & + & + & + & + & + & + & 100 \\
\hline $\mathrm{Q}_{4}$ & - & - & - & - & - & + & - & 14 & + & + & + & + & + & + & + & 100 \\
\hline $\mathrm{Q}_{5}$ & - & + & - & - & + & - & + & 42 & + & + & + & + & + & + & + & 100 \\
\hline $\mathrm{Q}_{6}$ & + & + & + & - & - & - & + & 57 & + & + & + & + & + & + & + & 100 \\
\hline $\mathrm{Q}_{7}$ & + & - & + & + & - & + & - & 57 & + & + & + & - & + & + & + & 85 \\
\hline $\mathrm{Q}_{8}$ & - & - & - & + & - & - & - & 14 & - & + & - & + & + & + & + & 71 \\
\hline $\mathrm{Q}_{9}$ & - & - & + & + & + & + & - & 57 & + & + & + & + & + & + & + & 100 \\
\hline $\mathrm{Q}_{10}$ & - & + & - & - & - & + & + & 42 & + & + & - & + & + & + & + & 85 \\
\hline Correct answer $(\%)$ & 30 & 40 & 30 & 30 & 40 & 50 & 40 & & 90 & 100 & 80 & 80 & 100 & 100 & 90 & \\
\hline
\end{tabular}


of the atom, matter, and solid in the pre-test were 30\%; in the post-test, all the students were able to answer these questions. While $57 \%$ and $14 \%$ of students were able to answer the seventh and eight questions relating to compound and pure substance in the pre-test, these percentages rose in the post-test to $85 \%$ and $71 \%$, respectively.

When we examine Figure 4 derived from Table 4, all of the students answered questions relating to the "atom," "matter," "liquid," "solid," and "gas" concepts. It would seem that the students' academic achievement was a result of the instructional design. In questions 3 and 4, this change was most dramatic increasing from $14 \%$ to $100 \%$.

Figure 5 derived from Table 3 shows the student-based achievement. Student-based achievement analysis shows that student $\mathrm{S}_{1}$ achieved $30 \%$ in the pre-test and $90 \%$ in the post- test. Similarly, student $\mathrm{S}_{2}$ and $\mathrm{S}_{7}$ 's $40 \%$ success rate in the pre-test increased to $100 \%$ in the post-test. Students $\mathrm{S}_{2}, \mathrm{~S}_{5}$, and $\mathrm{S}_{6}$ were able to answer all post-test questions.

\section{Analysis of Interview to Determine Students' Conceptual Learning Levels}

The results of the analysis of semi-structured interviews to determine the students' conceptual understanding level after the application of the instructional design are presented in this section. Analysis of students' answers to interview questions is shown in Table 5. In Table 5, correct answers are marked as plus and wrong answer as minus. There are two percentages of correct answers sections in the table. The first one is placed at the bottom of the table shows the percentage of correct answers that a student gave to all questions. Second one shows the percentage of correct answers that students gave to each

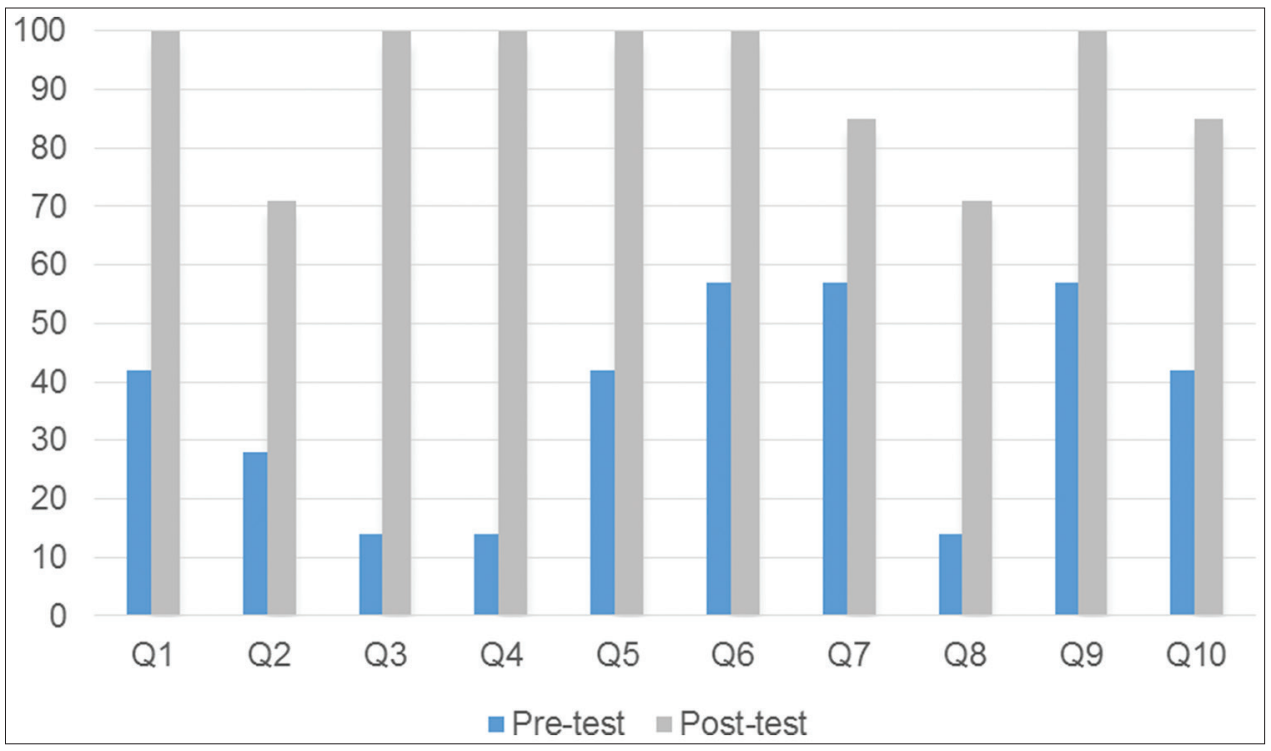

Figure 4: Question-based analysis of pre-test and post-test

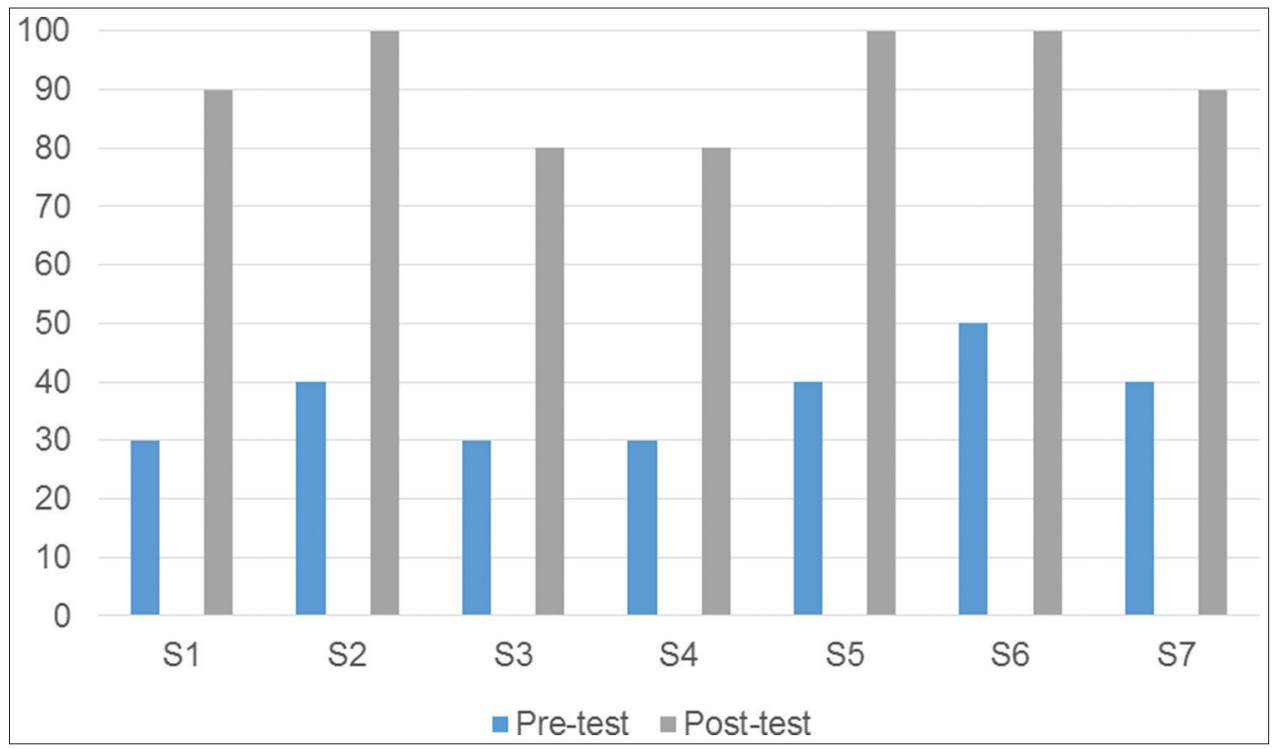

Figure 5: Student-based analysis of pre-test and post-test 


\begin{tabular}{|c|c|c|c|c|c|c|c|c|}
\hline \multirow[t]{3}{*}{ Concepts or subjects } & \multicolumn{8}{|c|}{ Learning level } \\
\hline & \multicolumn{7}{|c|}{ Students } & \multirow[t]{2}{*}{ Correct answer (\%) } \\
\hline & $\mathrm{S}_{1}$ & $\mathrm{~S}_{2}$ & $\mathrm{~S}_{3}$ & $\mathrm{~S}_{4}$ & $S_{5}$ & $\mathrm{~S}_{6}$ & $\mathrm{~S}_{7}$ & \\
\hline Atom & + & + & + & + & + & + & + & 100 \\
\hline Elements & + & - & + & + & + & + & - & 71 \\
\hline Matter & + & + & + & + & + & + & + & 100 \\
\hline Solid & + & + & + & + & + & + & + & 100 \\
\hline Liquid & - & + & + & + & + & + & - & 71 \\
\hline Gas & + & + & + & + & + & + & + & 100 \\
\hline Compound & + & + & + & + & + & + & + & 100 \\
\hline Pure substance & + & + & - & + & + & + & + & 71 \\
\hline Heterogeneous mixture & + & + & + & - & + & + & - & 71 \\
\hline Homogeneous mixture & + & + & - & + & + & + & - & 71 \\
\hline Correct answer (\%) & 90 & 90 & 90 & 90 & 100 & 100 & 60 & \\
\hline
\end{tabular}

question. All of the students were able to answer questions related to atom, matter, solid, gas, and compound concepts. $71 \%$ of the students were able to answer the questions related to the element, liquid, pure substance, heterogeneous, and homogenous mixture. Moreover, $\mathrm{S}_{1}, \mathrm{~S}_{2}, \mathrm{~S}_{3}$, and $\mathrm{S}_{4}$ students were able to answer $90 \%$ of the interview questions, while $\mathrm{S}_{5}$ and $\mathrm{S}_{6}$ students answered all the questions of the interview. However, $\mathrm{S}_{7}$ student was able to answer $60 \%$ of the interview questions.

\section{RESULTS AND CONCLUSION}

Students with visual impairments need a variety of accommodations to explore and examine real materials or models together with some adaptations in the environment to have safe and full access to science (Kizılaslan and Sözbilir, 2018; Wild and Trundle, 2010). This study concluded that the activities and materials that were prepared and designed according to student's priority can successfully take place if an appropriate teaching method is adopted. A teacher's teaching method is one of the most important adaptations to make science accessible to visually impaired students (Kumar et al., 2001).

In this study, an instructional design was prepared for students who were blind or who had low vision by taking into account the needs of the students. The student handouts, materials, activities, and teacher activity guide were developed in light of the information obtained from the needs analysis sample. This study found that the instructional design that aimed to teach the concepts related to the "structure of matter" contributed positively to the students' overall learning and achievement.

In the need analysis, students stated that they were not successful in multiple-choice items. Some students expressed this situation as: "I cannot make comparisons between choices," "I sometimes can take a little long and I miss the choices of the question," or "I cannot remember the choices." In line with this unique need, it was deemed appropriate to determine the students' actual achievement by conducting an interview. At the same time, the number of questions in the academic achievement test was kept low. 10 multiple-choice test items were prepared to cover all subjects and concepts. Although they had success in these academic achievement tests, the result of interview analysis was higher than the academic achievement tests. Only 10 questions were asked in the interview of which some of them were in-depth questions. According to the question-based analysis of interviews, while the achievement percentage of students responding to questions varied between 71 and 100, the student-based achievement varies between 90 and 100. On the other hand, question-based analysis of achievement test, while students' achievement ranged between $14 \%$ and $57 \%$ for the pre-test, it increased to between $71 \%$ and $100 \%$ in the post-test. If we examine the student-based academic achievement of the test, it varied between $30 \%$ and $50 \%$ for pre-test and $80 \%$ and $100 \%$ for the post-test. Accordingly, it can be contributed to students' science concepts learning with the instructional design that is designed and developed in terms of the needs of the students.

As a result, teachers can make science lessons more accessible to students with visual impairments through collaboration and specific adaptations in both the science classroom and laboratory. For all students to have equitable opportunities to engage in science, there is a need for classroom practices which remedy provide the right accommodations, modifications and assistive technology, and instructional support. Given the fact that understanding the needs of individual students with low vision and blindness plays multiple roles in shaping the lives of learners. Many science concepts are presented graphically, and there are many concepts that cannot be explored by touch and are put across through visual observation. To be able to provide equitable opportunities for students with visual impairment, it is clear that the first stage is to understand the needs of individual students with low vision and blindness.

\section{REFERENCES}

Allen, H.B. (1971). Principles of informant selection. American Speech, 46, 47-51. 
Anderson, T., \& Shattuck, J. (2012). Design-based research: A decade of progress in education research? Educational Researcher, 41(1), 16-25.

Andrews, S. (1998). Using inclusive literature to promote positive attitudes toward disabilities. Journal of Adolescent and Adult Literacy, $41,420-426$

Batd, V. (2014). The effect of activity-based learning approach on academic achievement: A meta-analytic and thematic study. E-International Journal of Educational Research, 5(3), 39-55.

Branch, R.M. (2009). Instructional Design: The ADDIE Approach. New York NY: Springer.

Breslyn, W., \& McGinnis, J.R. (2011). A comparison of exemplary biology, chemistry, earth science, and physics teachers' conceptions and enactment of inquiry. Science Education, 96(1), 48-77.

Browder, D.M., Trela, K., Courtade, G.R., Jimenez, B. A., Knight, V., \& Flowers, C. (2010). Teaching mathematics and science standards to students with moderate and severe developmental disabilities. The Journal of Special Education, 46(1), 26-35.

Bybee, R., McCrae, B., \& Laurie, R. (2009). PISA 2006: An assessment of scientific literacy. Journal of Research in Science Teaching, 46(8), 865-883.

Byrne, B. (2014). Getting in and getting on? The experiences of young people with visual impairments and hearing impairments in thirdlevel education. International Journal of Disability, Development and Education, 61(2), 119-133.

Çakmak, S., Karakoç, T., Şafak, P., \& Kan, A. (2014). Identifying the reading speed of low vision student's at elementary level. International Journal in IT and Engineering, 2(10), 38-48.

Calderon, R., \& Naidu, S. (1999). Further support of the benefits of early identification and intervention with children with hearing loss. Volta Review, 100, 53-84.

Cawley, J.F. (1994). Science for students with disabilities. Remedial and Special Education, 15, 67-71.

Collins, A., Joseph, D., \& Bielaczyc, K. (2004). Design research: Theoretical and methodological Issues. Journal of the Learning Sciences, $13(1), 15-42$.

Dani, D. (2009). Scientific literacy and purposes for teaching science: A case study of lebanese private school teachers. International Journal of Environmental and Science Education, 4(3), 289-299.

Erwin, E., Perkins, T., Ayala, J., Fine, M., \& Rubin, E. (2001). You don't have to be sighted to be a scientist, do you? Issues and outcomes in science education. Journal of Visual Impairment and Blindness, 95(6), 338-352.

Fradd, S.H., \& Lee, O. (1995). Science for all: A promise of a pipe dream. Bilingual Research Journal, 19, 261-278.

Fraser, W.J., \& Maguvhe, M.O. (2008). Teaching life sciences to blind and visually impaired learners. Journal of Biological Education, 42, 84-89.

Gast, D.L., Winterling, V., Wolery, M., \& Farmer, J.A. (1992). Teaching firstaid skills to students with moderate handicaps in small group instruction. Education and Treatment of Children, 15, 101-124.

Gurganus, S., Janas, M., \& Schmitt, L. (1995). Science instruction: What special education teachers need to know and what roles they need to play. Teaching Exceptional Children, 27(4), 7-9.

Hadary, D., \& Cohen, S. (1978). Science Activities for Blind, Deaf, and Emotionally Disturbed Students. College Park, MD: University Park Press.

Hartmann, E.S. (2013). A socio-cognitive approach to how children with deaf blindness understand symbols. International Journal of Disability, Development, and Education, 59, 131-144.

Individuals with Disabilities Education Act (IDEA). (2004). Individuals with Disabilities Education Improvement Act of 2004. Available from: http:// www.ed.gov/office/OSERS/Policy/IDEA/the law.html. [Last retrieved on 2018 Aug 04].

Kızılaslan, A., \& Kizılaslan, M. (2018). Anxiety in visually impaired students about the future. The International Journal of Evaluation and Research in Education, 7(2), 152-158.

Kızılaslan, A., \& Sözbilir, M. (2018). Maddenin halleri ve ısı öğretim tasarım modelinin değerlendirilmesi öğrenci ve öğretmen görüşleri. Marmara Üniversitesi Ĕ̈itim Bilimleri Dergisi, 48(48), 111-127

Kumar, D., Ramasamy, R. \& Stefanich, G. (2001). Science for students with visual impairments: Teaching suggestions and policy implications for secondary educators. Electronic Journal of Science Education, $5(3), 25-78$.

Maguvhe, M.O. (2003). Being a blind researcher in South Africa: A critical assessment, Perspectives in Education, 21(3), 117-119.

Mastropieri, M.A., \& Scruggs, T.E. (1992). Science for students with disabilities. Review of Educational Research, 62, 377-411.

McGrail, E., \& Rieger, A. (2013). Increasing disability awareness through comics literature. Electronic Journal for Inclusive Education, 3(1), 1-21.

Merriam, S.B. (1998). Qualitative Research and Case Study Applications in Education. San Francisco: Jossey-Bass Publishers.

Millar, R. (2006). Twenty first century science: Insights from the design and implementation of ascientific literacy approach in school science. International Journal of Science Education, 28(13), 1499-1521.

National Committee on Science Education Standards and Assessment (NSES). (1993). National Science Education Standards: An Enhanced Sampler. Washington, DC: National Research Council.

Patton, J.R., \& Andre, K.E. (1989). Individualizing for science and social studies. In: Wood, J., (Ed.), Mainstreaming: A Practical Approach for Teachers. Columbus, OH: Merrill. p301-351.

Rule, A. (2011). Tactile Earth and space science materials for students with visual impairments: Contours, craters, asteroids, and features of Mars. Journal of Geoscience Education, 59, 205-218.

Scruggs, T.E., \& Mastropieri, M.A. (1993). Current approaches to science education: Implications for mainstream instruction of students with disabilities. Remedial and Special Education, 14(1), 15-24

Thomas, H., \& Imrie, R. (2008). The interrelationships between environment and disability. Local Environment, 13, 477-483.

Tindal, G., \& Nolet, V. (1994). Instruction and learning in middle school science classes: Implications for students with disabilities. The Journal of Special Education, 28(2), 166-187.

Wild, T., \& Trundle, K. (2010). Conceptual understandings of seasonal change by middle school students with visual impairments. Journal of Visual Impairment Blindness, 104(2), 107-108.

Wild, T.A., Hilson, M.P., \& Hobson, S.M. (2013). The conceptual understanding of sound by students with visual impairments. Journal of Visual Impairment Blindness, 107, 107-116.

Wright, J.C., \& Wright, C.S. (1998). A commentary on the profound changes envisioned by the national science standards. Teachers College Record, $100,122-144$

Yin, R.K. (2014). Case Study Research: Design and Methods. $5^{\text {th }}$ ed.). California, SAGE Publication. 


\section{APPENDIX 1:}

Student activity guide

Name of the Activity: Let's explain how matter is made up of small particles.

\section{Materials}

Magnetic balls

Glass balls

Cologne

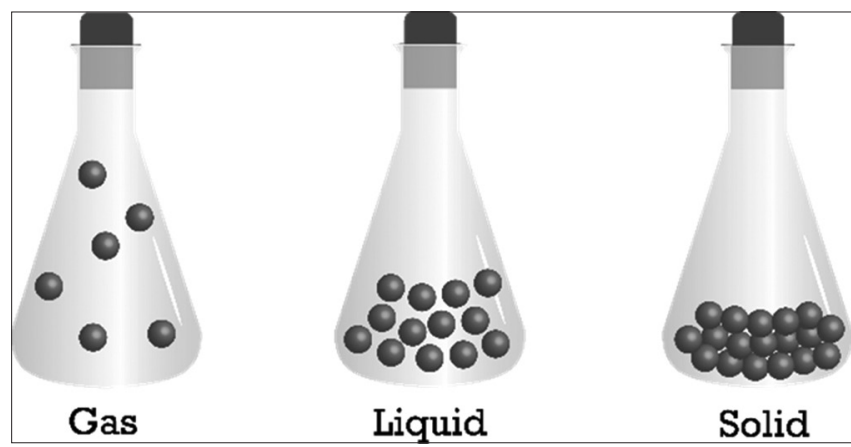

\section{Let's Make the Activity}

1. Let's examine activity materials to students by touching.

2. Examine glass balls and describe forces between particles.

3. Examine magnetic balls and describe forces between particles.

4. Drops little cologne on hand and wait for a few minutes

5. Let's define interaction between particles.

6. Explain how the substance changes its state from a solid to a liquid and from a liquid to a gas.

\section{APPENDIX 2}

Activity guide for blind student

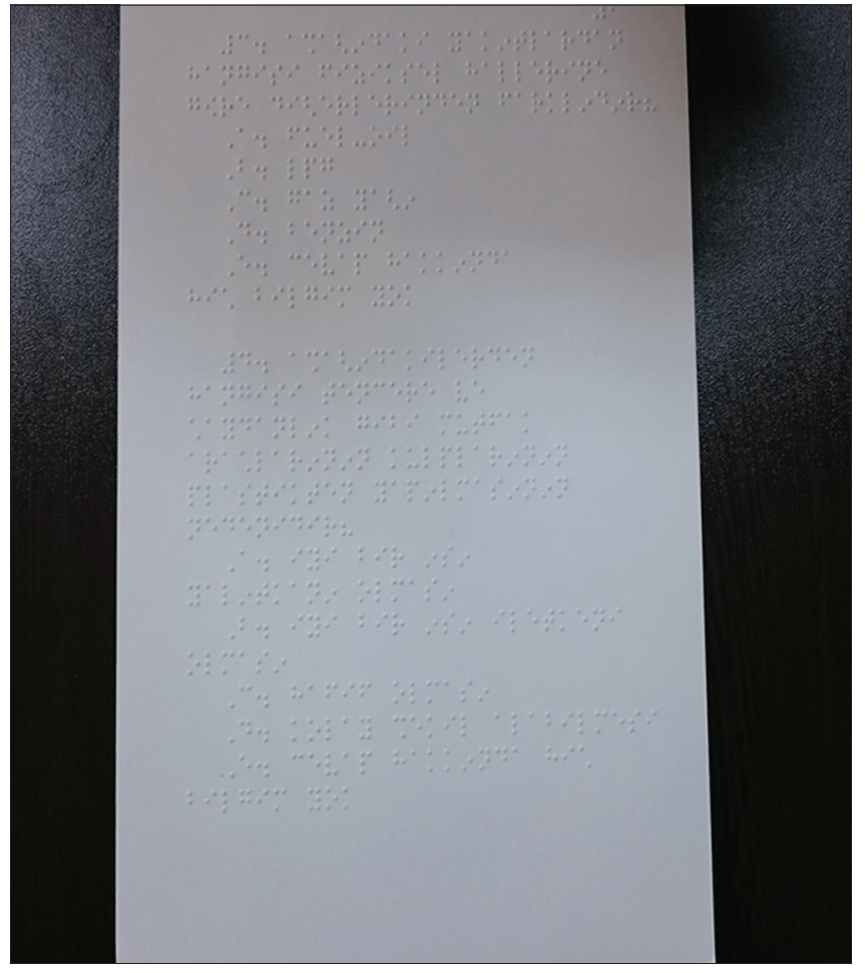

